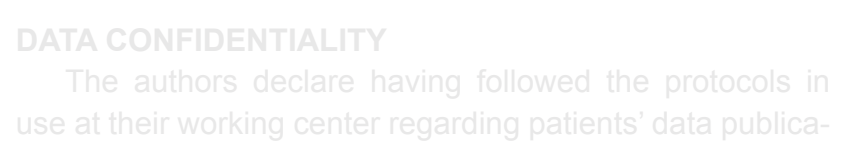

FUNDING SOURCES

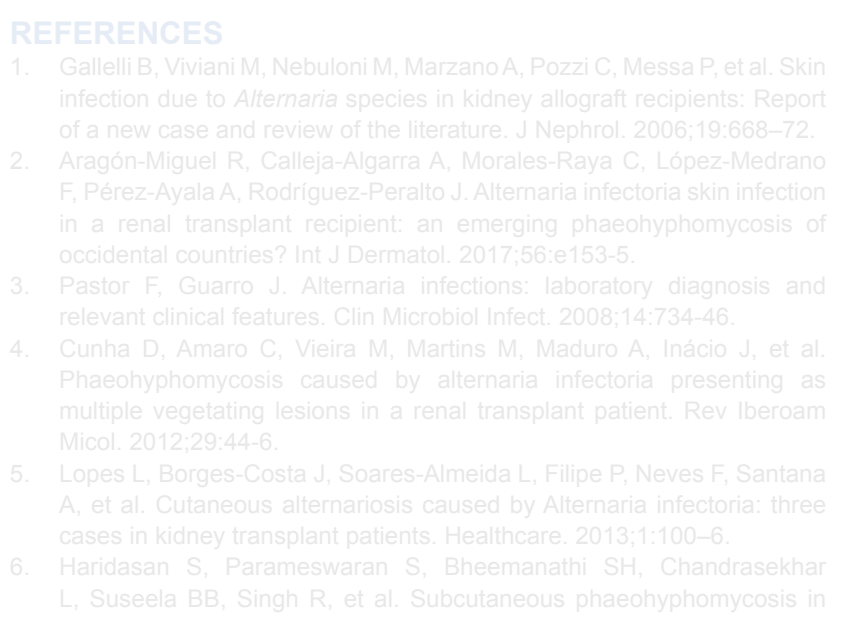

\title{
Non-Secretory Multiple Myeloma with Patchy Marrow Involvement and Aberrant Cytokeratin Expression
}

\section{Mieloma Múltiplo Não-Secretor Com Envolvimento "Patchy" da Medula Óssea e Expressão Aberrante de Citoqueratinas}

Miguel SILVA ${ }^{1}$, Joana MARTINS², João PINTO³ ${ }^{3}$ Teresina AMARO ${ }^{3}$

Acta Med Port 2021 Nov;34(11):778-781 • https://doi.org/10.20344/amp.13235

\begin{abstract}
Non-secretory multiple myeloma is a rare form of the disease that presents a diagnostic challenge. A 69-year-old woman presented to the emergency department with a pathological fracture of the right clavicle, along with a history of asthenia and middle back pain in the preceding three months. Workup revealed multiple focal lytic bone lesions in the clavicles, ribs, skull and thoracic- lumbar-sacral spine, without evidence of anemia, hypercalcemia or renal failure, with no abnormal immunofixation in the serum or urine and with normal serum free light chain ratios. The liac crest bone marrow aspiration and biopsy revealed a scarcely involved marrow, However, biopsy of one of the focal bone lesions revealed a hypercellular bone marrow with phenotypically abnormal plasmocytes, along with an intriguing, albeit aberrant, cytokeratin expression. Non-secretory multiple myeloma is in itself a rare diagnosis. However, the combination of a patchy marrow involvement and aberrant cytokeratin expression makes this a noteworthy presentation.
\end{abstract}

Keywords: Fractures, Spontaneous; Keratins; Multiple Myeloma; Plasma Cells

\section{RESUMO}

O mieloma múltiplo não-secretor é uma forma rara da doença e um desafio diagnóstico. Uma mulher de 69 anos recorreu ao serviço de urgência com uma fratura patológica da clavícula direita e uma história de astenia e dorsalgia com três meses de evolução. A

1. Serviço de Medicina Interna. Hospital Pedro Hispano. Unidade Local de Saúde de Matosinhos. Matosinhos. Portugal.

2. Serviço de Hematologia. Hospital Pedro Hispano. Unidade Local de Saúde de Matosinhos. Matosinhos. Portugal.

3. Serviço de Anatomia Patológica. Hospital Pedro Hispano. Unidade Local de Saúde de Matosinhos. Matosinhos. Portugal.

$\triangle$ Autor correspondente: Miguel Silva. leuguimerius@gmail.com

Recebido: 08 de dezembro de 2019 - Aceite: 01 de junho de 2020 - First published: 08 de setembro de 2021 - Online issue published: 02 de novembro de 2021 Copyright @ Ordem dos Médicos 2021 
investigação revelou múltiplas lesões ósseas focais osteolíticas nas clavículas, costelas, crânio e coluna dorso-lombo-sagrada, sem evidência de anemia, hipercalcemia ou insuficiência renal, sem imunofixação anormal no soro ou na urina e com rácios de cadeias leves livres normais. O aspirado e biópsia de medula óssea da crista ilíaca revelou um escasso envolvimento por plasmócitos. No entanto, a biópsia de uma das lesões focais revelou uma medula hipercelular com plasmócitos fenotipicamente anormais e com uma aberrante expressão de citoqueratinas. O mieloma múltiplo não-secretor é por si só um diagnóstico raro. Contudo, a combinação de envolvimento irregular da medula e a expressão aberrante de citoqueratinas são merecedoras de atenção.

Palavras-chave: Fraturas Espontâneas; Mieloma Múltiplo; Plasmócitos; Queratinas

\section{INTRODUCTION}

Multiple myeloma (MM) is a plasma cell neoplasm that represents approximately $10 \%$ of all hematologic malignancies and $1 \%$ of all malignancies. ${ }^{1}$

A typical presentation of MM involves the presence of multiple osteolytic bone lesions, evidence of a monoclonal (M) protein component, as well as evidence of end-organ damage usually in the form of renal failure, hypercalcemia, and anemia (CRAB features). Bone lesions can be severe to the point of causing pathological fractures and bone pain is a presenting symptom in the majority of patients. ${ }^{2,3}$

Diagnosis is usually established by either demonstrating bone marrow $(\mathrm{BM})$ involvement with $\geq 10 \%$ clonal plasma cells and/or pathological evidence of a solitary plasmacytoma (a single lesion comprised of plasma cells), along with a combination of CRAB and/or a few other biomarkers (> $60 \%$ BM plasmacytosis, serum free light chain ratio (sFLC) $\geq 100$ and $>1$ focal lesion on magnetic resonance imaging). Nearly all patients with MM have an M protein component that is secreted by the clonal plasma cells (comprised of a combination of immunoglobulin heavy and/or light chains), which can be detected with immunofixation of serum and/or urine. $^{4}$

However, in about $3 \%$ of patients, there is a form of MM that shows no evidence of secretion of an $\mathrm{M}$ protein and is called non-secretory MM. ${ }^{5-7}$

The sFLC, an assay that quantifies the ratio of serum kappa and lambda free light chains, allows further identification of true non-secretory MM, since monoclonal sFLC can be detected in up to $60 \%$ of patients without a quantifiable M protein. ${ }^{8,9}$

MM involvement of the bone marrow can sometimes be patchy and this heterogenous involvement can lead to sampling errors and difficulty in establishing the diagnosis, especially in non-secretory $\mathrm{MM}^{{ }^{7}}$

It has been rarely reported that cytokeratin expression, namely AE1/AE3 and CAM5.2, usually associated with the epithelial nature of tissue and tumors such as carcinomas, can be positive in immunohistochemistry studies of plasma cell neoplasms and represents a serious pitfall in the differential diagnosis. ${ }^{10}$

Regardless of non-secretory status, treatment of MM involves systemic induction therapy and, in select cases, autologous stem cell bone marrow transplant. Patients with non-secretory $\mathrm{MM}$ seem to have improved survival when compared with secretory MM. ${ }^{11}$

\section{CASE REPORT}

We report the case of a 69-year-old woman that presented to the emergency department with a pathological fracture of the right clavicle and an accompanying history of asthenia and middle-lower back pain in the preceding three months.

The patient had no anemia, no renal failure and no hypercalcemia. Serum electrophoresis revealed a slight beta2 fraction peak, along with an elevation of serum IgA of 621 $\mathrm{mg} / \mathrm{dL}$ and $\beta 2$-microglobulin of $2.09 \mathrm{mg} / \mathrm{L}$. However, there was no evidence of clonality in the serum or urine detected on immunofixation and the serum light chain ratios were normal.

Imaging of the skeleton (using combined modalities of skeleton radiography, computed tomography-CT and magnetic resonance imaging-MRI) revealed diffuse osteopenia and the presence of several focal osteolytic lesions involving the skull, the right clavicle, the left scapula, several ribs and several thoracic, lumbar and sacral vertebrae and the iliac bones.

The iliac bone marrow examination showed a plasma cell count of $<1 \%$ on the myelogram and this was confirmed on bone marrow biopsy. These results were reproduced on repeat bone marrow examination. On multiparameter flow cytometry immunophenotyping, the plasmocytes showed an abnormal profile of CD38+, CD138+, CD19-, CD56CD10-, CD20-, CD117+, CD45-.

Further imaging with FDG PET-CT (Fig. 1) revealed several focal lytic bone lesions with increased metabolic activity as well as increased activity in abdominal and pelvic adenopathies, in the cervix and in a small region in the left gluteal muscle.

One of the lesions in the thoracic spine vertebrae was biopsied (Fig. 2) and showed bone marrow with increased cellularity mostly comprised of plasmablasts and mature and immature plasma cells, with immunohistochemistry revealing expression of CD138, Kappa light chain restriction, as well as positivity for cytokeratins AE1/AE3 and CAM5.2, as well as negativity for CD20 and CD3, CK7, CK20, TTF1 , estrogen receptors, Melan-A, S100, synaptophysin and chromogranin.

Further biopsies of the gluteal muscle and cervix found no plasma cell infiltration.

A diagnosis of non-secretory multiple myeloma with patchy marrow involvement and aberrant cytokeratin expression was established. The patient had good response to induction therapy.

\section{DISCUSSION}

Non-secretory MM is a rare presentation of the disease and often an elusive diagnosis. One cannot rely on evidence of an $\mathrm{M}$ protein component since it cannot be quantified by 


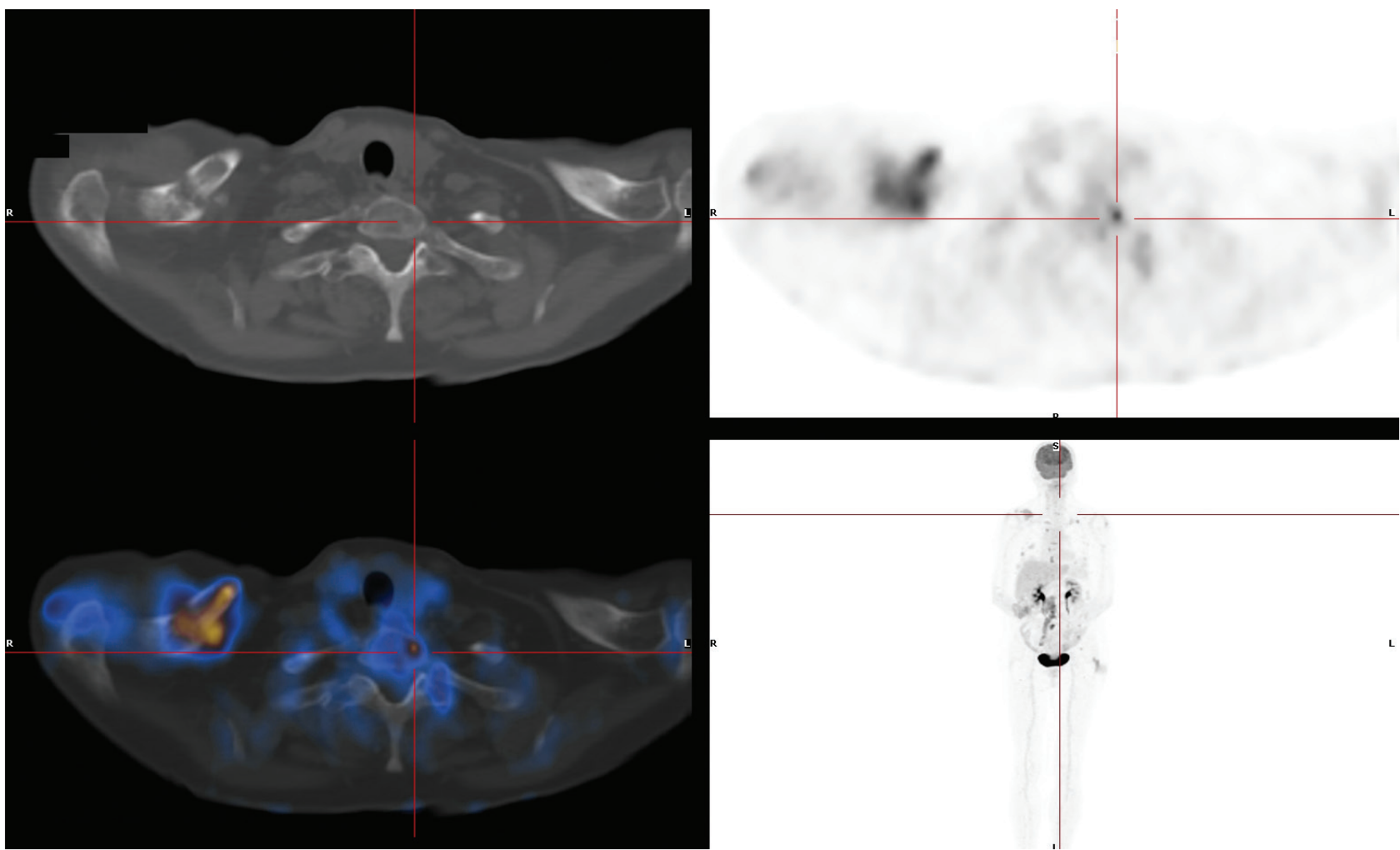

Figure 1 - FDG PET-CT on the left showing clavicle fracture and osteolytic thoracic spine vertebrae lesions, both metabolically active and, on the right, a delayed enhancement sagittal view of the overall burden of the metabolically active osteolytic lesions
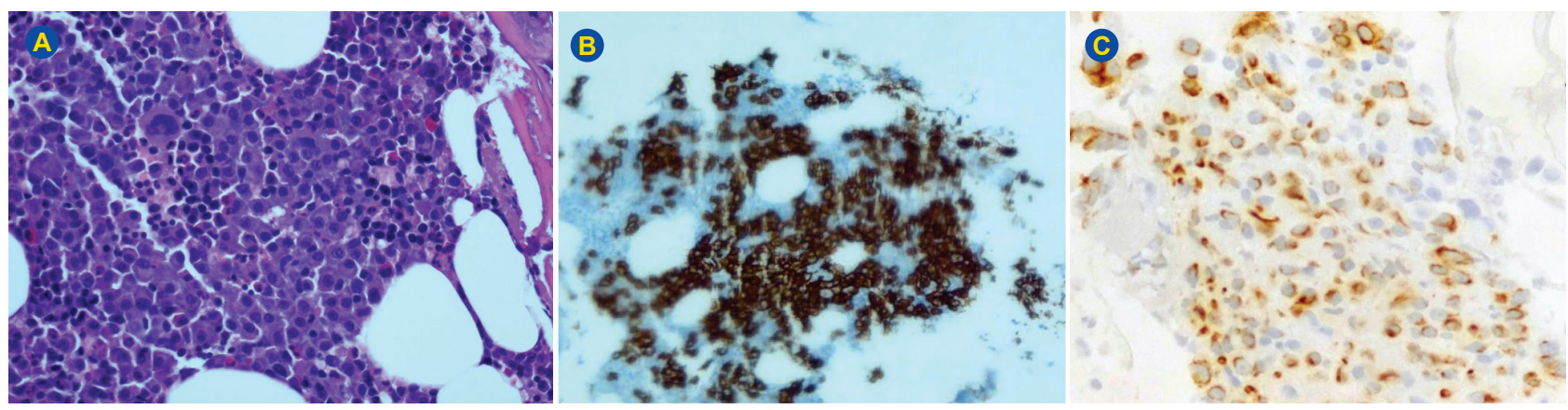

Figure 2 - Clusters and sheets of plasma cells with cytologic atypia (A), expression of CD138

(B) and expression of cytokeratin $\mathrm{AE} 1 / \mathrm{AE} 3$ (C)

current assays. Furthermore, with occasionally patchy and heterogenous involvement of the bone marrow, establishing clonality by means of plasmocyte counts can be a difficult task, often requiring multiple bone marrow samples in multiple locations.

Not infrequently, low plasmocyte counts after bone marrow aspiration represent hemodilution of the sample with peripheral blood. In these cases, comparison with the bone marrow biopsy sample confirms the sampling error. ${ }^{12} \mathrm{How}-$ ever, in our case, the bone marrow biopsy of the aspiration site in the iliac crest was also hypocellular, which leads us to believe that this patient had patchy marrow infiltration.

As for the aberrant cytokeratin expression found in this case, past research ${ }^{10,13,14}$ has revealed that it might not be so 'aberrant' after all. Wotherspoon et al, ${ }^{10}$ in 1989 found that five out of 14 cases of plasma cell neoplasms expressed cytokeratin markers, and the authors viewed this as a potential diagnostic pitfall, since occult metastatic carcinoma (especially if poorly differentiated) can simulate a similar clinical phenotype.

While treatment of non-secretory MM is similar to its secreting counterpart, monitoring the response to treatment in non-secretory MM relies more often on PET-CT scans and frequent bone marrow sampling. ${ }^{7}$ Multiparameter flow cytometry immunophenotyping is able to evaluate the presence of minimal residual disease (MRD) and is recommended in order to guide need for further treatment. ${ }^{7}$

\section{CONCLUSION}

Non-secretory MM is a diagnostic challenge that must always be present in the differential diagnosis of multiple osteolytic bone lesions even in the absence of typical features of multiple myeloma such as $\mathrm{M}$ protein secretion and CRAB features. 


\section{AUTHORS CONTRIBUTION}

MS: Draft of the manuscript.

JM, JP, TA: Critical review of the manuscript.

\section{PROTECTION OF HUMANS AND ANIMALS}

The authors declare that the procedures were followed according to the regulations established by the Clinical Research and Ethics Committee and to the Helsinki Declaration of the World Medical Association updated in 2013.

\section{DATA CONFIDENTIALITY}

The authors declare having followed the protocols in use at their working center regarding patients' data publication.

\section{REFERENCES}

1. Jemal A, Siegel R, Xu J, Ward E. Cancer statistics, 2010. CA Cancer J Clin. 2010;60:277-300.

2. Kyle R, Gertz M, Witzig T, Lust J, Lacy M, Dispenzieri A, et al. Review of 1027 patients with newly diagnosed multiple myeloma. Mayo Clin Proc. 2003;78:21-33.

3. Rajkumar SV. Multiple myeloma: 2018 update on diagnosis, riskstratification, and management. Am J Hematol. 2018;93:1091-110.

4. Rajkumar S, Dimopoulos M, Palumbo A, Blade J, Merlini G, Mateos $\mathrm{M}$, et al. International Myeloma Working Group updated criteria for the diagnosis of multiple myeloma. Lancet Oncol. 2014;15:e538-48.

5. Bladé J, Kyle R. Nonsecretory myeloma, immunoglobulin D myeloma, and plasma cell leukemia. Hematol Oncol Clin North Am. 1999;13:125972.

6. Cavo M, Galieni P, Gobbi M, Baldrati L, Leardini L, Baccarani M, et al. Nonsecretory multiple myeloma. Presenting findings, clinical course and prognosis. Acta Haematol. 1985;74:27-30.

7. Dupuis M, Tuchman S. Non-secretory multiple myeloma: from biology to clinical management. Onco Targets Ther. 2016;9:7583-90.

8. Drayson M, Tang L, Drew R, Mead G, Carr-Smith H, Bradwell A. Serum free light-chain measurements for identifying and monitoring patients

\section{INFORMED CONSENT}

The authors declare that the patient's informed consent was obtained.

\section{COMPETING INTERESTS}

All authors report no competing interests.

\section{FUNDING SOURCES}

The authors declare that there were no subsidies or grants funding the study.

with nonsecretory multiple myeloma. Blood. 2001;97:2900-2.

9. Shaw G. Nonsecretory plasma cell myeloma becoming even more rare with serum free light-chain assay: a brief review. Arch Pathol Lab Med. 2006;130:1212-5.

10. Wotherspoon A, Norton A, Isaacson P. Immunoreactive cytokeratins in plasmacytomas. Histopathology. 1989;14:141-50.

11. Chawla S, Kumar S, Dispenzieri A, Greenberg A, Larson D, Kyle R, et al. Clinical course and prognosis of non-secretory multiple myeloma. Eur $\mathrm{J}$ Haematol. 2015;95:57-64.

12. Lee N, Moon S, Lee JH, Park HK, Bang SM, Lee J, et al. Discrepancies between the percentage of plasma cells in bone marrow aspiration and BM biopsy: Impact on the revised IMWG diagnostic criteria of multiple myeloma. Blood Cancer J. 2017;7:e530.

13. Suzuki $H$. The aberrant expression of cytokeratin in plasma cell neoplasm. UHOD. Akademi Doktorlar Yayinevi. 2017;27:69-73.

14. Petruch $\mathrm{U}$, Horny $\mathrm{H}$, Kaiserling $\mathrm{E}$. Frequent expression of haemopoietic and non-haemopoietic antigens by neoplastic plasma cells: an immunohistochemical study using formalin-fixed, paraffin-embedded tissue. Histopathology. 1992;20:35-40. 